\title{
Tekemällä oppimista loppuun asti
}

Leinonen Niina, Partanen Timo \& Palviainen Petri (2002). Tiimiakatemia. Tositarina tekemällä oppivasta yhteisöstä. PS-KUSTANNUS

\section{Tiimiakatemia-kirja}

esittelee Jyväskylän ammattikorkeakoulun markkinoinnin ja yrittäjyyden erikoisyksikön, Tiimiakatemian, taustaa, ideologiaa ja toimintaa. Kirja jakautuu neljään osaan, joista ensimmäisessä käsitellään Tiimiakatemian taustalla vaikuttavia malleja ja ideologiaa. Toinen ja kolmas osa keskittyvät oppivaan yhteisöön sekä oppivaan yksilöön yhteisön jäsenenä. Neljäs luku tarkastelee asioita valmentajan (ent. opettaja tai opintojen ohjaaja) näkökulmasta. Kirja on rönsyilevä, vähän epätasainen, vuolas, innostunut ja loppujen lopuksi varsin vakuuttava. Luultavasti juuri tällainen on myös oppimisyhteisö, josta kirja kertoo.

\section{Lukemisen aikana kirja} ehti sekä ärsyttää että innostaa. Lopputulos jäi selvästi myönteiselle puolelle, vaikka ensimmäisen osan jälkeen olin aika epäilevä. Kirjan ensimmäisessä luvussa esitellään Kolben kokemuksellisen oppimisen mallia, Nonakan ja Takeuchin käsityksiä tiedosta sekä mm. Sengen oppivaa organisaatiota koskevia ajatuksia. Tämän jälkeen lanseerataan oppimisyhteisön teoreettiseksi perustaksi "Aivoteoreettinen malli”, josta yhdistellään em. teoreetikkojen ajatuksia.

Aivoteoreettinen malli tuntui ja tuntuu edelleen sanahirviöltä, mutta se on ehkä makuasia.

\section{Vakavammin tässä}

mallissa häiritsee se, että siitä tulee mieleen huonossa mielessä johtamisoppaat, joissa otetaan asemansa lunastaneiden teoreetikkojen ideat, liimataan päälle uusi nimi ja sen jälkeen esitetään vanhat ajatukset omina. Tätä vaikutelmaa vahvistaa vielä lukuisat "C Timo Partanen" -merkinnät. Mallin rakentamisessa ei missään tapauksessa varasteta, koska lähteet mainitaan asianmukaisesti, mutta ainakaan minä en ymmärrä, mitä lisäarvoa asioiden nimittäminen "Aivoteoreettiseksi malliksi" ja siihen liittyvät lukuisat prosessikuvat tuovat.

\section{Aivoteoreettisen mallin} toimivuutta korostetaan useampaan kertaan, mutta näyttö jää epäselväksi. Esimerkiksi sivulla 27 on todetaan: "...tämä malli tai teoria on osoittanut toimivuutensa käytännössä....", mutta selkeitä osoituksia toimivuudesta ei esitetä. Kirjan liitteenä esitellään itsearviointiin perustuvan laatuarvioinnin tuloksia, jota voidaan pitää ainakin epäsuorana tukena mallille, mutta olisi helppo löytää myös muita toiminnan onnistumista kuvaavia asioita. Itselleni tulee lähinnä mieleen kaksi suuntaa, josta evidenssiä pitäisi kertyä. Tiimiakatemian keskeinen työskentelytapa on toteuttaa projekteja todellisille asiakkaille. Tällöin esimerkiksi asiakkaiden tyytyväisyys, uusintaostojen määrä tai vastaavat tiedot olisivat lukijan kannalta kiinnostavia. Kirjan liitteenä on esitelty Tiimiakatemian tuloskortti, jossa on mm. asiakassuhteisiin liittyviä mittareita, mutta mittaustuloksia ei kerrota tai sitten mittauksia ei ole tehty.

\section{Toinen suunta on}

oppiminen ja opiskelijoiden menestys opintojen jälkeen: sijoittuvatko Tiimiakatemian opiskelijat nopeammin tai paremmin työelämään kuin muut ammattikorkeakoulujen markkinoinnin opiskelijat, millä tavalla Tiimiakatemian käyneiden osaamistaso eroaa muista jne. "Todistusaineiston" niukka esittely ei tietenkään heikennä itse asiaa, mutta sen esittäminen kannattaisi, koska se vahvistaisi innostuneen ja omaan asiaansa uskovan tekstin uskottavuutta.

\section{Kun kirjassa siirrytään} kuvaamaan Tiimiakatemian käytäntöjen kehittymistä ja arkipäivän työtä, niin kiinnostus kasvaa nopeassa tahdissa. Yhteisön ja tiimien rakentumista kuvataan toimitiloja myöden. Tästä osasta on opittavaa paitsi muilla oppimisyhteisöillä niin myös työyhteisöillä, koska samat teemat ja ongelmat nousevat esiin toistuvasti tiimityöhön ja muuhun yhteistoimintaan liittyen.

\section{Erityisen hienoa oli} lukea erilaisista keskustelufoorumeista, jotka yhteisöön ja tiimeihin on luotu. Foorumien omaperäisen nimet - esimerkiksi "Synnytys" ja "Linnunlaulu" - ovat sisäistä yhtenäisyyttä luovia tekijöitä, 
mutta ulkopuoliselle niiden merkitys ei ole sama. Jotkut lukuisista Tiimiakatemian "omista sanoista" kuulostavat jopa oudoilta, mutta niiden sisällöt ovat hienoa luettavaa. Oppivaa organisaatiota esittelevässä kirjallisuudessa erilaisten keskustelufoorumien merkitys tuodaan aina esiin työyhteisön, luovuuden ja oppimisen mahdollistajina, mutta harvemmin näkee, että tällaiset foorumit myös tuodaan näin kiinteäksi osaksi jokapäiväistä työskentelyä.

\section{Mielenkiintoinen osa}

on myös kuvaus oppimisen ja arvioinnin käytännöistä. Todelliset asiakasprojektit, yrittäjyyden harjoittelu oikeassa yrityksessä, johtamistaitojen kehittäminen projektityössä, kirjallisuusesseet ja eri osapuolten (itse, asiakas, projektiryhmä, valmentaja) tekemät arvioinnit muodostavat ainutlaatuisen kokonaisuuden. Tiimiakatemian oppimistapa ei varmaan sovellu kaikille aloille eikä kaikille ihmisille yhtä hyvin, mutta missä tahansa oppilaitoksessa kannattaisi vakavasti harkita, mistä asioista voisi ottaa mallia ja luoda omaan ympäristöön sopivia sovelluksia Tiimiakatemian käytännöistä. Tämän osuuden lukemisen jälkeen itselleni tuli olo, että jos olisin nyt aloittamassa opintoja, niin tämänkaltainen oppimisympäristö olisi erinomaisen innostava ainakin minulle.

\section{Yksilön näkökulmaa}

tarkasteltaessa Sengen Personal mastery on yksi keskeinen käsite. Itseohjautuvuus, henkilökohtainen kehittyminen ja henkinen kasvu tulevat esiin puheiden lisäksi erilaisissa oppimisen muodoissa. Oppi- missopimus, itsearviointi, palautteen saaminen muilta opiskelijoilta ja valmentajalta ovat työtapoja, joissa korostuu vastuun ottaminen omasta oppimisesta ja kehittymisestä työelämään kasvavana ihmisenä.

\section{Tiimiakatemian opettajia}

kutsutaan valmentajiksi ja heidän roolinsa onkin kuvauksen perusteella selvästi oppimisen ja yhteisön johtajuudessa eikä niinkään tiedon tai taidon välittämisessä. Tämä osuus on taas sellainen, josta voisi ammentaa niin opettaja kuin kuka tahansa esimies työyhteisössä, jossa osaamisen johtaminen on tärkeällä sijalla. Harvat asiat ovat suoraan siirrettävissä esimerkiksi it-yrityksen arkeen, mutta hyviä ideoita siitä, miten yhteisössä voidaan tuottaa ja jakaa tietoa, kirjasta kyllä saa.

\section{Valmentajan rooli} vaikuttaa monipuoliselta ja vaativalta. Olisikin ollut mie- lenkiintoista lukea valmentajan tehtävien ja roolien lisäksi enemmän siitä, kuinka Tiimiakatemiassa ylläpidetään johtajuutta: miten ylläpidetään valmentajien taitoa ja intoa toteuttaa oppimisen johtamista haastavassa ympäristössä.

\section{Kirjan innostuneisuus}

ja markkinointipuhe herättää välillä epäilyjä, että "onkohan se nyt noin hienoa". Samoin konkreettisten näyttöjen vähäisyys, joita käsiteltiin edellä sekä jotkut muut asiat jättävät jälkeensä avoimia kysymyksiä, mutta silti "lukeminen kannattaa aina" pätee tähän kirjaan. Se on ehkä parhaimmillaan ajatuksia ja ideoita herättävä lukemisto opetustyötä tekeville sekä esimiehille, jotka pyrkivät tekemään omasta työyhteisöstään oppivan organisaation. Ainakin se rohkaisee uskomaan siihen, että asioita voi tehdä toisin, jos vain tahtoo ja uskaltaa.

Esa Pohjanheimo 